\title{
Soil Test Based Fertilizer Prescriptions through Integrated Nutrient Management Using Targeted Yield Approach for SRI Rice (Var. Swarna) in Vertisols of Chhattisgarh, India
}

\author{
Vedhika Sahu*, L.K. Srivastava and V.N. Mishra \\ Soil Science and Agricultural Chemistry, Indira Gandhi Krishi Vishwavidyalaya, \\ Raipur-492012, Chhattishgarh, India \\ *Corresponding author
}

\begin{tabular}{l} 
K e y w o r d s \\
INM, STCR, Rice, \\
SRI, FYM, Vertisol. \\
Article Info \\
$\begin{array}{l}\text { Accepted: } \\
\text { 26 August } 2017 \\
\text { Available Online: } \\
\text { 10 September } 2017\end{array}$ \\
\hline
\end{tabular}

Keywords

INM, STCR, Rice, SRI, FYM, Vertisol.

Article Info

Accepted:

Available Online:

September 2017

\section{Introduction}

Rice is the staple food for more than half of the total population and hence a key pillar for food security. India produces rice in a large quantity with a production of 104.4 million tonnes and productivity of $2367 \mathrm{~kg} \mathrm{ha}^{-1}$ in 2015-16, grown in an area of 44.1 million hectares. Rice is grown in Chhattisgarh in an area of 37.18 lakh hectares with a production of 66.20 lakh tonnes and productivity of 1780 $\mathrm{kg} \mathrm{ha}^{-1}$ in 2015-16. Rice plants perform better when they are not flooded continuously and even better when the SRI practices are followed. Today SRI is being adopted in many states in India and the response from farmers has been overwhelming seeing the benefits of the method. SRI is a combination of several practices those include changes in nursery management, time of transplanting, water and weed management.

Fertilizers are generally applied to crops on the basis of generalized state level fertilizer recommendations. However, the fertilizer requirement of a crop is not a static one and it may vary for the same crop from soil to soil and even from field to field on the same soil. Soil testing as a diagnostic tool, the value of soil testing in both general and specific terms 
is to identify soil fertility problems and constraints in an area and to give specific fertilizer recommendation based on soil analysis of a farm holding.

Keeping the above facts in view and nonavailability of STCR data for SRI rice crop (Var. Swarna), the present investigation was contemplated in vertisol soils so as to elucidate the significant relationship between soil test values and crop responses to fertilizer and to develop fertilizer prescription equations under IPNS for desired yield target of rice crop.

\section{Materials and Methods}

A field experiment was conducted at the farm of Indira Gandhi Krishi Vishwavidyalaya, Raipur (Chhattisgarh) on soil test crop response correlation with SRI rice (variety Swarna) during two kharif consecutive season in 2015-16 and 2016-17 in Vertisol. The soil of the experimental field comes under the soil order of Vertisol. This soil is locally known as Kanhar and identified as Arang II series. It is clayey in texture with $24.3 \%$ Sand, $21.4 \%$ silt and $54.3 \%$ clay, dark brown to black in color, neutral to alkaline in reaction due to presence of lime concretion in lower horizon. The soil is deep to 1-1.5 meter. The structure varied from coarse angular blocky to massive and cloddy and in few cases from prismatic or columnar. Soil is represented as typical fine montmorillonitic, hyperthermic, udic chromustert. Some physico-chemical properties of experimental soil were analyzed which found $7.8 \mathrm{pH}(1: 2.5), 0.19 \mathrm{EC}\left(\mathrm{dSm}^{-1}\right)$, 36.32 CEC (c mol $\left.(\mathrm{p}+) \mathrm{kg}^{-1}\right), 5.8$ Organic C ( $\mathrm{g}$ $\left.\mathrm{kg}^{-1}\right), 223$ Available $\mathrm{N}\left(\mathrm{kg} \mathrm{ha}{ }^{-1}\right), 18.5$ Available P $\left(\mathrm{kg} \mathrm{ha}^{-1}\right)$ and 500 Available K (kg $\left.\mathrm{ha}^{-1}\right)$. The experiment was conducted according to approved layout plan of All India Coordinated Research project for Investigation on Soil Test Crop Response Correlation (STCR). A special field technique developed by Ramamurthy et al., (1967) was used for this study. The field was divided in to three equal long strips and denoted as $\mathrm{L}_{0}$, $\mathrm{L}_{1}$ and $\mathrm{L}_{2}$. Prior to conducting the actual field experiment, a fertility gradient was created by applying the graded doses of $\mathrm{N}, \mathrm{P}$ and $\mathrm{K}$ fertilizer for obtaining the appropriate variation in soil fertility in different strips. Variation in soil fertility with respect to N, P and $\mathrm{K}$ were created by applying 100-75-50 and 200-150-100, $\mathrm{kg} \mathrm{ha}^{-1}$ of $\mathrm{N}, \mathrm{P}_{2} \mathrm{O}_{5}$ and $\mathrm{K}_{2} \mathrm{O}$ in $\mathrm{L}_{1}$ and $\mathrm{L}_{2}$ strip, respectively and keeping $\mathrm{L}_{0}$ strip as unfertilized (control). Fodder maize crop was grown during summer season 2015 as a preparatory crop so that fertilizer could interact with soil, plant and microbes and thus become a part of soil system. In this way by growing the exhaust crop, the ranges of soil fertility were created in the fertility strips which were evaluated in terms of variations in fodder yields and soil test values. After the harvest of the fodder crop, the main complex experiment with SRI rice was conducted in subsequent kharif season. Each strip was divided in to three equal sizes for three levels of FYM $\quad\left(0,5\right.$ and $\left.10 \mathrm{t} \mathrm{ha}^{-1}\right)$ and was treated as block. A representative sample of applied FYM was analyzed for nutrient content and resulted as $0.4,0.3,0.8$ percent $\mathrm{N}$, $\mathrm{P}$ and $\mathrm{K}$ respectively. The 24 selected fertilizer treatments constituted 4 levels of each of $\mathrm{N}\left(0,60,120\right.$ and $\left.180 \mathrm{~kg} \mathrm{ha}^{-1}\right), \mathrm{P}_{2} \mathrm{O}_{5}$ $\left(0,40,80\right.$ and $\left.120 \mathrm{~kg} \mathrm{ha}^{-1}\right)$ and $\mathrm{K}_{2} \mathrm{O}(0,40,80$ and $\left.120 \mathrm{kgha}^{-1}\right)$. These were distributed in each block of the strips having 8 treatments in each block.

The fertilizer materials were used as urea, single supper phosphate and muriate of potash for the source of $\mathrm{N} \mathrm{P}$ and $\mathrm{K}$ nutrient, respectively. Full dose of $\mathrm{P}_{2} \mathrm{O}_{5}$ and $\mathrm{K}_{2} \mathrm{O}$ and $1 / 3$ rd of $\mathrm{N}$ were applied as basal, remaining $2 / 3$ rd of $N$ applied in two equal splits as top dressing at tillering and panicle initiation stages. Grain and straw samples were analyzed for N, P and K content (Piper 1966) 
and total nutrient uptake was computed using grain and straw yield data. Using the data on grain yield, nutrient uptake, pre-sowing soil available nutrients and fertilizer doses applied the basic parameter, viz. nutrient requirement $\left(\mathrm{kg} \mathrm{q}^{-1}\right)$, contribution of nutrients from soil and fertilizer sources were calculated as described by Ramamoorthy et al., (1967). The contribution of nutrients from applied FYM was estimated by relating the yield with fertilizer nutrients and FYM. These parameters were used for the formulation of fertilizer adjustment equations for deriving fertilizer doses and the soil test based fertilizer prescription in the form of ready reckoners for desired yield target of rice under $\mathrm{N}, \mathrm{P}, \mathrm{K}$ alone as well as IPNS.

\section{Results and Discussion}

Soil test levels as affected by past fertilization

As per the approach suggested by Ramamurthy (1967), variation in soil fertility was deliberately created by adding graded fertilizer doses (Table 1) and maize was sown as exhaust crop during summer season, 2015 so that the added nutrients may naturally transform in to the soil system. Fodder yield of maize in different fertility strips indicated that gradient in fertility level exists. After harvest of maize crop, soil samples were analyzed from each strip. Maize yield and soil test data (Table 1) show that there were little variations in soil test $\mathrm{N}$ (alkaline $\mathrm{KMnO}_{4}-\mathrm{N}$ ). However, the variations in Olsen's $\mathrm{P}$ were quite marked and ammonium acetate extractable-K did not reflect variations in different fertility strips. Gradient with respect to $\mathrm{P}$ was observed quite marked, as the nature of $\mathrm{P}$ is immobile and subjected to fix in soil particularly high in Vertisols. Phosphorus ions react very quickly with soil constituents to form insoluble compounds depending on the nature of soil, and thus remains in soil. However, there was no gradient created with respect to $\mathrm{N}$ and $\mathrm{K}$ as the nature of $\mathrm{N}$ in soil is very dynamic and its different forms are subjected to losses through leaching volatilization and de-nitrification. The high $\mathrm{K}$ status of the experimental field soil and maintenance of its dynamic equilibrium might be the possible reason for almost the same soil test $\mathrm{K}$ levels in all strips.

\section{Status of available NPK in soil}

Before taking the main complex experiment with rice during kharif season 2015 and 2016, the soil samples from each plot were taken and analyzed for available N, P and K. Table 2 reveals the range and means values of available nutrients ( $\mathrm{N}, \mathrm{P}$ and $\mathrm{K}$ ) during two rice seasons. As discussed in previous section, the data indicate no variations in soil test $\mathrm{N}$ across the fertility strips in both the rice season. Mean values on soil $\mathrm{N}$ ranged from 217-228 and 216-229 $\mathrm{kg} \mathrm{ha}^{-1}$ during 2015 and 2016 kharif season, respectively. The level of soil $\mathrm{P}$ increased with respect to fertility strips from $\mathrm{L}_{0}$ to $\mathrm{L}_{2}$. Average soil $\mathrm{P}$ ranged from $12.26-26.12$ and $16.96-26.64 \mathrm{~kg} \mathrm{ha}^{-1}$ in two rice seasons. The available $\mathrm{K}$ status did not reflect with respect to fertility strips indicating that the soil of experimental field is well supplied with K.

\section{Response of rice to added nutrients}

The results (Table 3) showed the range and average values of rice yields in relation to fertility strips during two rice crop seasons. The ranges of rice yields were recorded as 36.21-92.27 $\mathrm{q} \mathrm{ha}^{-1}$ with average of $72.15 \mathrm{q} \mathrm{ha}^{-}$ ${ }^{1}$ in $\mathrm{L}_{0}$ strip, $40.48-95.57 \mathrm{q} \mathrm{ha}^{-1}$ with average of $76.55 \mathrm{q} \mathrm{ha}^{-1}$ in $\mathrm{L}_{1}$ strip and 43.60-98.33 q $\mathrm{ha}^{-1}$ with average of $79.22 \mathrm{q} \mathrm{ha}^{-1}$ in $\mathrm{L}_{2}$ strip during first rice season 2015. It was also noticed that standard deviation (SD) and per cent coefficient of variation (CV) levels were higher in $\mathrm{L}_{0}$ strip and they reduced under $\mathrm{L}_{1}$ and $\mathrm{L}_{2}$ strips. Similar trends were also observed during next rice season 2016. This 
indicates that variation in soil test values was higher in $\mathrm{L}_{0}$ strip than those of $\mathrm{L}_{1}$ and $\mathrm{L}_{2}$ strips which reflected on crop yields. The increase in rice grain yields with respect to fertility strips may be due to fertility gradient in soil $\mathrm{P}$ status from $\mathrm{L}_{0}$ to $\mathrm{L}_{2}$ strip.

The relation of rice yields with different plant nutrients as independent variables were derived by regression analysis for both the seasons of rice crop to evaluate the yield variations due to various nutrients and presented in the Table 4. Results indicate that the larger proportion of variation in the rice grain yield during both the seasons was accounted for by $\mathrm{N}$ alone.

Therefore, its quadratic term also similarly fit into the data as evidence from the higher $\mathrm{R}^{2}$ value (0.86 and 0.83) with curvilinear equation in both (2015 and 2016) the seasons. High response of rice was attributed to the high $\mathrm{N}$ requirement and being a mobile nature of this element, it is accessible to the plant in the root system sorption zone (Ramamoorthy et al., 1967).

Fertilizer $\mathrm{P}$ and $\mathrm{K}$ were the next to explain the rest of variations. The $\mathrm{P}$ ions react very quickly with soil constituents to form insoluble compounds and are thus rendered immobile in the soil. Furthermore, the requirement of $\mathrm{P}$ nutrient in rice is lower than $\mathrm{N}$. The curvilinear nature of rice yield response to $\mathrm{P}$ application can therefore be attributed to the above facts. Application of fertilizer $\mathrm{N}$ and $\mathrm{P}$ explained the $92 \%$ yield variation as reflected in the equation and by inclusion of fertilizer $\mathrm{K}$ did not contribute much towards crop yields. Maximum yield variations recorded $(93 \%)$ when all three major nutrients were added. Similar yield variation was recorded when FYM also included with three major nutrients. This indicates that FYM contribution is very poor towards yield variation as the nutrient content and their release pattern may be lower. The rice responses to fertilizer N, P, K and FYM during two rice seasons $(2015 \&$ 2016) have also been depicted in Figs. 4.1 to 4.4 on above facts. Mahindar Kumar et al., (2009), Pandey et al., (2009), Singh et al., (2009) and Banerjee and Pal (2009) have reported on responses of different crops to applied N, P, K and FYM.

\section{Relationship between yield and nutrient uptake}

A close association was observed between the yield of SRI rice and total N, P and K uptake during both the crop seasons (2015 and 2016). This relation was used to estimate the nutrient requirement for rice (Table 5). The nutrient requirement (NR) is defined as the amount of nutrient required to produce unit amount of yield. The nutrient requirement can be given by the regression coefficient $\left(b_{1}\right)$ of yield $(\mathrm{Y})$ and total nutrient uptake (U).

$\mathrm{Y}=\mathrm{b}_{1} \mathrm{U}$ or $\mathrm{U}=1 / \mathrm{b}_{1} * \mathrm{Y}$

Where, $1 / b_{1}$ gives the NR (Nutrient Requirement)

Table.1 Fertilizer doses added to various strips and fodder yield of maize during summer season, 2015 to create fertility gradient (Pre-requisite for main complex experiment)

\begin{tabular}{|c|c|c|c|c|c|c|c|}
\hline \multirow{2}{*}{$\begin{array}{c}\text { Fertility } \\
\text { Strips }\end{array}$} & \multicolumn{3}{|c|}{ Fertilizer doses $\left(\mathrm{kg} \mathrm{ha}^{-1}\right)$} & \multirow{2}{*}{$\begin{array}{c}\text { Fodder } \\
\text { yield }\left(\mathrm{t} \mathrm{ha}^{-1}\right)\end{array}$} & \multicolumn{3}{|c|}{ Post-harvest soil test values $\left(\mathrm{kg} \mathrm{ha}^{-1}\right)$} \\
\hline & $\mathbf{N}$ & $\mathbf{P}_{2} \mathbf{O}_{5}$ & $\mathrm{~K}_{2} \mathrm{O}$ & & $\mathbf{S N}$ & SP & SK \\
\hline $\mathbf{L}_{\mathbf{0}}$ & 0 & 0 & 0 & 18.96 & 217 & 12.26 & 497 \\
\hline $\mathbf{L}_{1}$ & 100 & 75 & 50 & 22.38 & 224 & 17.30 & 501 \\
\hline $\mathbf{L}_{2}$ & 200 & 150 & 100 & 26.84 & 228 & 26.12 & 502 \\
\hline
\end{tabular}


Table.2 Range and average values of available N, P and K ( $\left.\mathrm{kg} \mathrm{ha}^{-1}\right)$ before SRI Rice (Kharif seasons, 2015 and 2016)

\begin{tabular}{|c|c|c|c|c|c|c|c|c|}
\hline \multirow{2}{*}{$\begin{array}{l}\text { Available } \\
\text { nutrients }\end{array}$} & \multicolumn{8}{|c|}{ Fertility strips } \\
\hline & $\mathbf{L}_{\mathbf{0}}$ & $\mathbf{L}_{1}$ & $\mathbf{L}_{2}$ & SD & $\mathbf{L}_{\mathbf{0}}$ & $\mathbf{L}_{1}$ & $\mathbf{L}_{2}$ & SD \\
\hline $\begin{array}{l}\text { Alkaline } \mathrm{KMnO}_{4}-\mathrm{N} \\
\left(\mathrm{kg} \mathrm{ha}^{-1}\right)\end{array}$ & $\begin{array}{c}194-238 \\
(217)\end{array}$ & $\begin{array}{l}208-241 \\
(224)\end{array}$ & $\begin{array}{c}211-245 \\
(228)\end{array}$ & 13.05 & $\begin{array}{c}183-246 \\
(216)\end{array}$ & $\begin{array}{l}201-249 \\
(226)\end{array}$ & $\begin{array}{c}199-257 \\
(229)\end{array}$ & 15.13 \\
\hline $\begin{array}{l}\text { Olsen P } \\
\left(\mathrm{kg} \mathrm{ha}^{-1}\right)\end{array}$ & $\begin{array}{c}10.59-13.73 \\
(12.26)\end{array}$ & $\begin{array}{c}13.69-21.02 \\
(17.30)\end{array}$ & $\begin{array}{l}21.63-31.50 \\
(26.12)\end{array}$ & 6.14 & $\begin{array}{c}9.25-27.57 \\
(16.96)\end{array}$ & $\begin{array}{c}10.88-26.91 \\
(18.44)\end{array}$ & $\begin{array}{l}19.97-37.56 \\
(26.64)\end{array}$ & 7.17 \\
\hline $\begin{array}{l}\text { Amm. acetate } \\
\text { extractable } \mathrm{K}(\mathrm{kg} \\
\left.\mathrm{ha}^{-1}\right)\end{array}$ & $\begin{array}{c}442-520 \\
(497)\end{array}$ & $\begin{array}{c}444-521 \\
(501)\end{array}$ & $\begin{array}{c}450-528 \\
(502)\end{array}$ & 24.08 & $\begin{array}{c}365-530 \\
(488)\end{array}$ & $\begin{array}{c}389-527 \\
(490)\end{array}$ & $\begin{array}{c}444-539 \\
(498)\end{array}$ & 33.42 \\
\hline
\end{tabular}

(Data in parenthesis are mean values)

Table.3 Range and mean of grain yields of SRI rice during kharif season 2015 and 2016 in relation to fertility strips

\begin{tabular}{|c|c|c|c|c|c|}
\hline \multirow{2}{*}{$\begin{array}{c}\text { Fertility } \\
\text { Strips }\end{array}$} & \multicolumn{3}{|c|}{ Grain yield $\left(q\right.$ ha $\left.^{-1}\right)$} & \multirow{2}{*}{ SD } & \multirow{2}{*}{ CV $(\%)$} \\
\hline & Minimun & Maximum & Average & & \\
\hline \multicolumn{6}{|c|}{ Kharif season, 2015} \\
\hline $\mathbf{L}_{\mathbf{0}}$ & 36.21 & 92.27 & 72.15 & 17.85 & 24.74 \\
\hline $\mathbf{L}_{1}$ & 40.48 & 95.57 & 76.55 & 16.31 & 21.31 \\
\hline $\mathbf{L}_{2}$ & 43.60 & 98.33 & 79.22 & 16.20 & 20.45 \\
\hline All strips & 36.21 & 98.33 & 75.97 & 16.83 & 22.15 \\
\hline \multicolumn{6}{|c|}{ Kharif season, 2016} \\
\hline $\mathbf{L}_{\mathbf{0}}$ & 38.00 & 94.33 & 73.95 & 18.51 & 25.02 \\
\hline $\mathbf{L}_{1}$ & 43.95 & 99.22 & 79.92 & 17.45 & 21.84 \\
\hline $\mathbf{L}_{2}$ & 46.90 & 104.65 & 84.50 & 17.21 & 20.36 \\
\hline All strips & 38.00 & 104.65 & 79.46 & 18.01 & 22.67 \\
\hline
\end{tabular}


Table.4 Selected regression model to account for yield variation of SRI Rice 2015 and 2016

\begin{tabular}{|c|c|c|}
\hline S.No. & $\begin{array}{c}\text { Model } \\
\text { SRI RICE 2015 }\end{array}$ & $\mathrm{R}^{2}$ \\
\hline 1 & $\mathrm{Y}=49.27+0.24 \mathrm{FN}$ & 0.86 \\
\hline 2 & $\mathrm{Y}=54.66+0.31 \mathrm{FP}$ & 0.56 \\
\hline 3 & $\mathrm{Y}=61.51+0.23 \mathrm{FK}$ & 0.28 \\
\hline 4 & $\mathrm{Y}=74.60+0.27 \mathrm{FYM}$ & 0.004 \\
\hline 5 & $\mathrm{Y}=47.91+0.24 \mathrm{FN}+0.27 \mathrm{FYM}$ & 0.86 \\
\hline 6 & $\mathrm{Y}=53.30+0.31 \mathrm{FP}+0.27 \mathrm{FYM}$ & 0.57 \\
\hline 7 & $\mathrm{Y}=60.14+0.23 \mathrm{FK}+0.27 \mathrm{FYM}$ & 0.29 \\
\hline 8 & $\mathrm{Y}=45.55+0.19 \mathrm{FN}+0.13 \mathrm{FP}$ & 0.92 \\
\hline 9 & $\mathrm{Y}=47.15+0.23 \mathrm{FN}+0.06 \mathrm{FK}$ & 0.87 \\
\hline 10 & $\mathrm{Y}=52.60+0.27 \mathrm{FP}+0.07 \mathrm{FK}$ & 0.59 \\
\hline 11 & $\mathrm{Y}=45.16+0.19 \mathrm{FN}+0.12 \mathrm{FP}+0.018 \mathrm{FK}$ & 0.93 \\
\hline 12 & $\mathrm{Y}=43.80+0.19 \mathrm{FN}+0.12 \mathrm{FP}+0.01 \mathrm{FK}+0.27 \mathrm{FYM}$ & 0.93 \\
\hline 13 & $\mathrm{Y}=10.53+0.18 \mathrm{SN}+0.21 \mathrm{FN}$ & 0.86 \\
\hline 14 & $\mathrm{Y}=49.71+0.28 \mathrm{SP}+0.31 \mathrm{FP}$ & 0.57 \\
\hline 15 & $\mathrm{Y}=5.08+0.11 \mathrm{SK}+0.23 \mathrm{FK}$ & 0.31 \\
\hline 16 & $\mathrm{Y}=47.29+0.32 \mathrm{FN}-0.0004 \mathrm{FN}^{2}$ & 0.86 \\
\hline 17 & $\mathrm{Y}=51.23+0.52 \mathrm{FP}-0.0017 \mathrm{FP}^{2}$ & 0.59 \\
\hline 18 & $\mathrm{Y}=57.78+0.44 \mathrm{FK}-0.0018 \mathrm{FK}^{2}$ & 0.31 \\
\hline 19 & $\mathrm{Y}=75-0.20 \mathrm{FYM}+0.04 \mathrm{FYM}^{2}$ & 0.005 \\
\hline \multicolumn{3}{|c|}{ SRI RICE 2016} \\
\hline 20 & $\mathrm{Y}=51.35+0.26 \mathrm{FN}$ & 0.83 \\
\hline 21 & $\mathrm{Y}=57.07+0.33 \mathrm{FP}$ & 0.54 \\
\hline 22 & $\mathrm{Y}=64.96+0.23 \mathrm{FK}$ & 0.25 \\
\hline 23 & $\mathrm{Y}=78.06+0.27 \mathrm{FYM}$ & 0.004 \\
\hline 24 & $\mathrm{Y}=49.95+0.26 \mathrm{FN}+0.27 \mathrm{FYM}$ & 0.83 \\
\hline 25 & $\mathrm{Y}=55.67+0.33 \mathrm{FP}+0.27 \mathrm{FYM}$ & 0.56 \\
\hline 26 & $\mathrm{Y}=64.01+0.23 \mathrm{FK}+0.19 \mathrm{FYM}$ & 0.25 \\
\hline 27 & $\mathrm{Y}=47.46+0.20 \mathrm{FN}+0.14 \mathrm{FP}$ & 0.89 \\
\hline 28 & $\mathrm{Y}=49.03+0.24 \mathrm{FN}+0.06 \mathrm{FK}$ & 0.84 \\
\hline 29 & $\mathrm{Y}=54.83+0.29 \mathrm{FP}+0.08 \mathrm{FK}$ & 0.56 \\
\hline 30 & $\mathrm{Y}=45.59+0.20 \mathrm{FN}+0.13 \mathrm{FP}+0.02 \mathrm{FK}+0.27 \mathrm{FYM}$ & 0.90 \\
\hline 31 & $\mathrm{Y}=32.98+0.09 \mathrm{SN}+0.23 \mathrm{FN}$ & 0.83 \\
\hline 32 & $\mathrm{Y}=49.86+0.52 \mathrm{SP}+0.28 \mathrm{FP}$ & 0.57 \\
\hline 33 & $\mathrm{Y}=23.39+0.08 \mathrm{SK}+0.22 \mathrm{FK}$ & 0.27 \\
\hline 34 & $\mathrm{Y}=46.91+0.20 \mathrm{FN}+0.13 \mathrm{FP}+0.02 \mathrm{FK}$ & 0.90 \\
\hline 35 & $\mathrm{Y}=49.32+0.34 \mathrm{FN}-0.0004 \mathrm{FN}^{2}$ & 0.83 \\
\hline 36 & $\mathrm{Y}=53.32+0.56 \mathrm{FP}-0.0018 \mathrm{FP}^{2}$ & 0.57 \\
\hline 37 & $\mathrm{Y}=60.87+0.47 \mathrm{FK}-0.002 \mathrm{FK}^{2}$ & 0.28 \\
\hline 38 & $\mathrm{Y}=78.49-0.23 \mathrm{FYM}+0.05 \mathrm{FYM}^{2}$ & 0.005 \\
\hline
\end{tabular}


Table.5 Relation of SRI Rice yield (Y) with total nutrient uptake (U)

\begin{tabular}{ccccc}
\hline \multirow{2}{*}{ Nutrient } & \multicolumn{2}{c}{$\mathbf{2 0 1 5}$} & \multicolumn{2}{c}{$\mathbf{2 0 1 6}$} \\
\cline { 2 - 5 } & $\mathrm{Y}=\mathbf{b}_{\mathbf{1}} \mathbf{U}$ & $\mathbf{R}^{\mathbf{2}}$ & $\mathbf{Y}=\mathbf{b}_{\mathbf{1}} \mathbf{U}$ & $\mathbf{R}^{\mathbf{2}}$ \\
\cline { 2 - 5 } $\mathrm{N}$ & $\mathrm{Y}=0.649 \mathrm{U}$ & 0.95 & $\mathrm{Y}=0.644 \mathrm{U}$ & 0.95 \\
$\mathrm{P}$ & $\mathrm{Y}=3.540 \mathrm{U}$ & 0.86 & $\mathrm{Y}=3.521 \mathrm{U}$ & 0.86 \\
$\mathrm{~K}$ & $\mathrm{Y}=0.584 \mathrm{U}$ & 0.88 & $\mathrm{Y}=0.591 \mathrm{U}$ & 0.91 \\
\hline
\end{tabular}

Table.6 Nutrient requirements for SRI Rice (var. Swarna)

\section{Nutrient}

\begin{tabular}{cccc} 
& \multicolumn{3}{c}{ rice $\left(\mathbf{k g ~ q}^{-\mathbf{1}}\right)$} \\
\cline { 3 - 4 } $\mathrm{N}$ & $\mathbf{2 0 1 5}$ & $\mathbf{2 0 1 6}$ & Mean \\
\cline { 3 - 4 } $\mathrm{P}$ & 1.54 & 1.55 & 1.54 \\
$\mathrm{~K}$ & 0.29 & 0.28 & 0.28 \\
& 1.72 & 1.69 & 1.70 \\
\hline
\end{tabular}

Table.8 Fertilizer adjustment equations for SRI Rice (Swarna)

\section{Nutrient requirement for one quintal grain yield of SRI}

rice $\left(\mathrm{kg} \mathrm{q}^{-1}\right)$

\begin{tabular}{|c|c|}
\hline 1 & $\mathrm{FN}=3.83 \mathrm{Y}-0.87 \mathrm{SN}-0.45 \mathrm{FYM}$ \\
\hline 2 & $F P=0.99 \mathrm{Y}-2.93 \mathrm{SP}-0.22 \mathrm{FYM}$ \\
\hline 3 & $\mathrm{FK}=1.66 \mathrm{Y}-0.16 \mathrm{SK}-0.105 \mathrm{FYM}$ \\
\hline
\end{tabular}


Table.7 Efficiencies of fertilizer, soil and FYM for SRI Rice

\begin{tabular}{cccccccccc}
\hline Nutrient & \multicolumn{3}{c}{ Nitrogen } & \multicolumn{3}{c}{ Phosphorus } & \multicolumn{3}{c}{ Potassium } \\
\cline { 2 - 9 } \begin{tabular}{c} 
Fertilizer \\
\cline { 2 - 8 } efficiency (\%)
\end{tabular} & $\mathbf{2 0 1 5}$ & $\mathbf{2 0 1 6}$ & Mean & $\mathbf{2 0 1 5}$ & $\mathbf{2 0 1 6}$ & Mean & $\mathbf{2 0 1 5}$ & $\mathbf{2 0 1 6}$ & Mean \\
$\begin{array}{c}\text { Soil Test } \\
\text { efficiency (\%) }\end{array}$ & 39.55 & 40.8 & 40.17 & 28.22 & 28.13 & 28.17 & 97.87 & 106.42 & 102.14 \\
$\begin{array}{c}\text { FYM } \\
\text { efficiency (\%) }\end{array}$ & 23.30 & 36.4 & 35.02 & 81.86 & 83.25 & 82.55 & 16.87 & 17.62 & 17.24 \\
\hline
\end{tabular}

Table.9 Ready reckoners for fertilizer N P and K recommendations based on soil test levels with 5 tons of FYM for SRI Rice (var. Swarna, 2015 and 2016) in Vertisols of Chhattisgarh

\begin{tabular}{|c|c|c|c|c|c|c|c|c|c|c|c|}
\hline \multicolumn{6}{|c|}{ Soil Test values (kg/ha) } & \multicolumn{6}{|c|}{ Yield Target of SRI Rice (q/ha) } \\
\hline \multirow[b]{2}{*}{$\mathbf{N}$} & \multirow[b]{2}{*}{$\mathbf{P}$} & \multirow[b]{2}{*}{$\mathbf{K}$} & \multicolumn{3}{|c|}{80 (q/ha) } & \multicolumn{3}{|c|}{90 (q/ha) } & \multicolumn{3}{|c|}{$100(q / h a)$} \\
\hline & & & $\mathbf{F N}$ & FP & FK & FN & FP & FK & $\mathbf{F N}$ & FP & FK \\
\hline 150 & 4 & 200 & 174 & 66 & 100 & 212 & 76 & 117 & 250 & 86 & 133 \\
\hline 175 & 6 & 225 & 152 & 61 & 96 & 190 & 70 & 113 & 229 & 80 & 129 \\
\hline 200 & 8 & 250 & 130 & 55 & 92 & 168 & 65 & 109 & 207 & 74 & 125 \\
\hline 225 & 10 & 275 & 108 & 49 & 88 & 147 & 59 & 105 & 185 & 69 & 121 \\
\hline 250 & 12 & 300 & 87 & 43 & 84 & 125 & 53 & 101 & 163 & 63 & 117 \\
\hline 275 & 14 & 325 & 65 & 37 & 80 & 103 & 47 & 97 & 142 & 57 & 113 \\
\hline 300 & 16 & 350 & 43 & 31 & 76 & 81 & 41 & 93 & 120 & 51 & 109 \\
\hline 325 & 18 & 375 & 21 & 25 & 72 & 60 & 35 & 89 & 98 & 45 & 105 \\
\hline 350 & 20 & 400 & 0 & 20 & 68 & 38 & 29 & 85 & 76 & 39 & 101 \\
\hline 375 & 22 & 425 & 0 & 14 & 64 & 16 & 24 & 81 & 55 & 33 & 97 \\
\hline 400 & 24 & 450 & 0 & 8 & 60 & 0 & 18 & 77 & 33 & 28 & 93 \\
\hline
\end{tabular}


Fig.1 Response of SRI Rice to different levels of FYM application and fertilizer $\mathrm{N}, \mathrm{P}_{2} \mathrm{O}_{5}$ and

$\mathrm{K}_{2} \mathrm{O}$ in kharif season 2015 \& 2016


Fertilizer N $\left(\mathrm{kg} \mathrm{ha}^{-1}\right)$
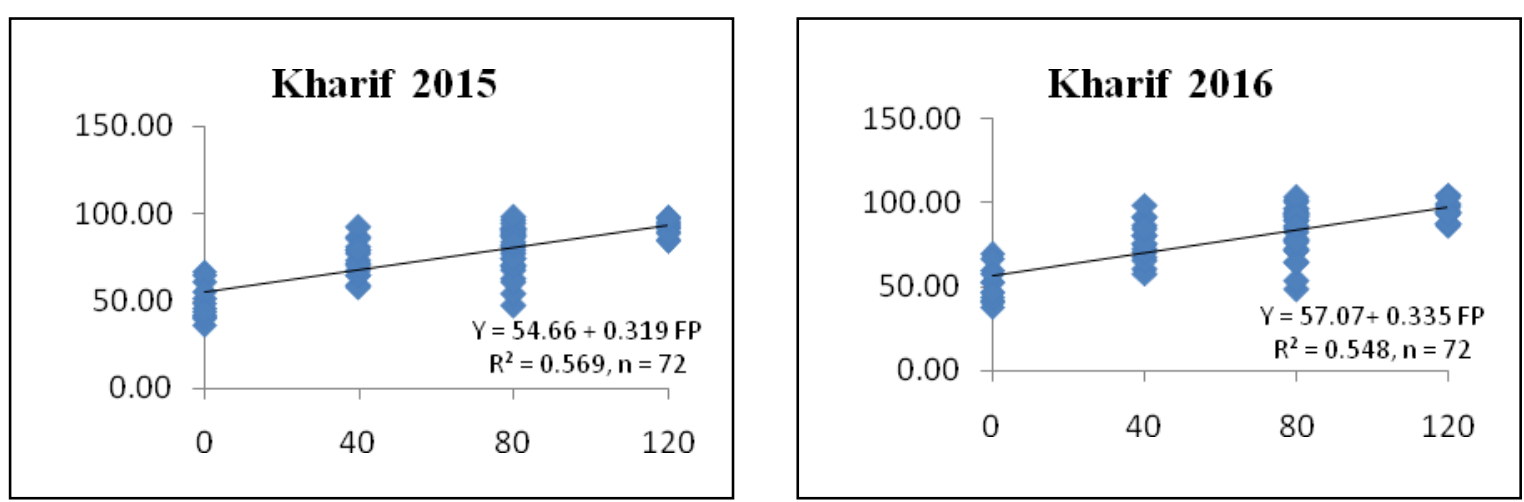

Fertilizer $\mathbf{P}\left(\mathrm{kg} \mathrm{ha}^{-1}\right)$
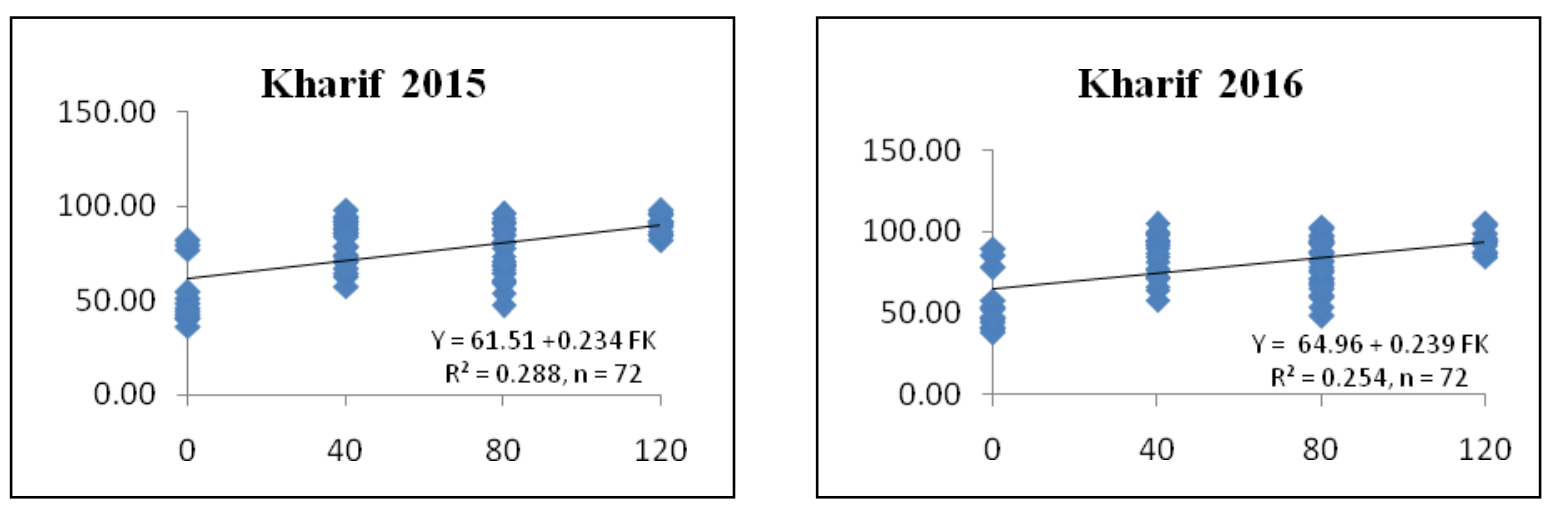

Fertilizer K $\left(\mathrm{kg} \mathrm{ha}^{-1}\right)$
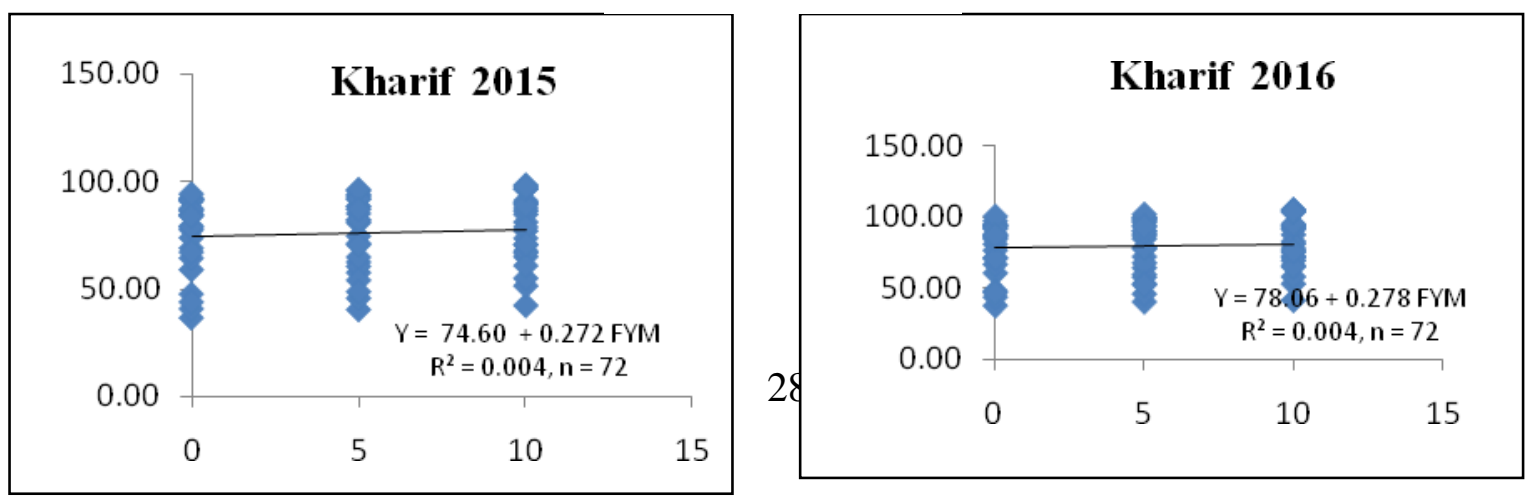

FYM $\left(q\right.$ ha $\left.^{-1}\right)$ 
Fig.2 Relationship between SRI Rice grain yield and Total NPK Uptake, Kharif season 2015 and 2016
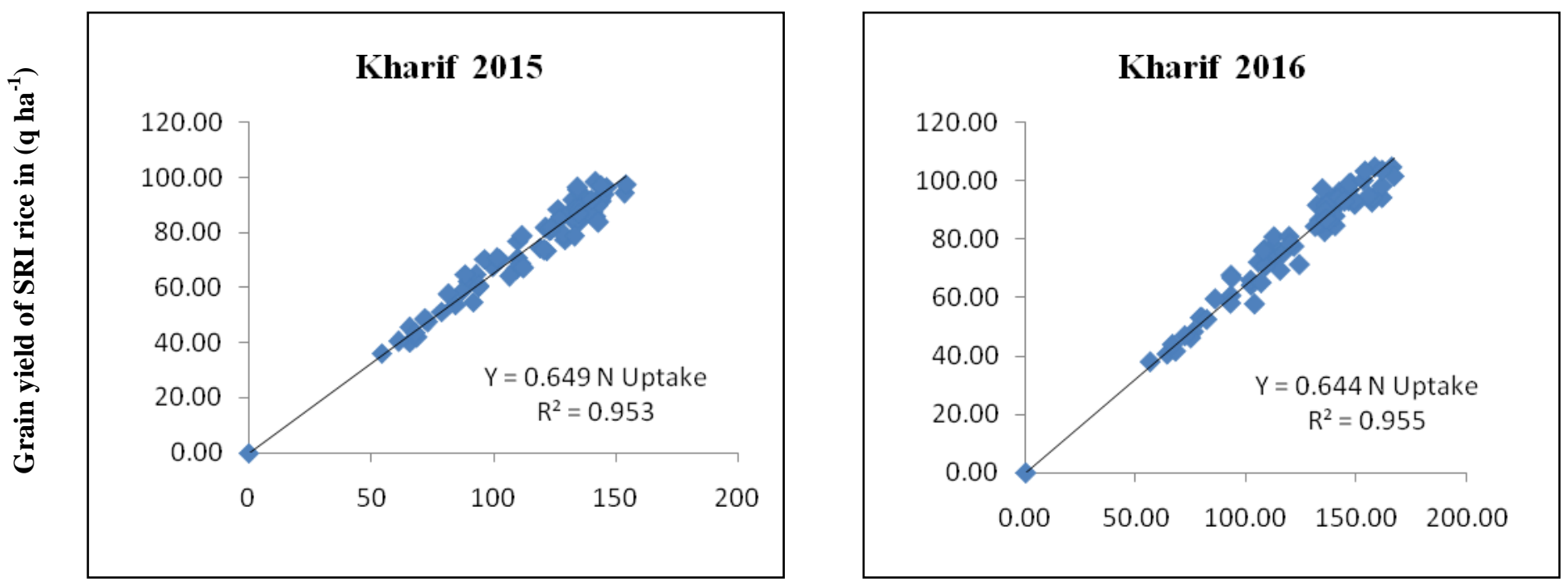

\section{Total N Uptake (kg ha $\left.{ }^{-1}\right)$}
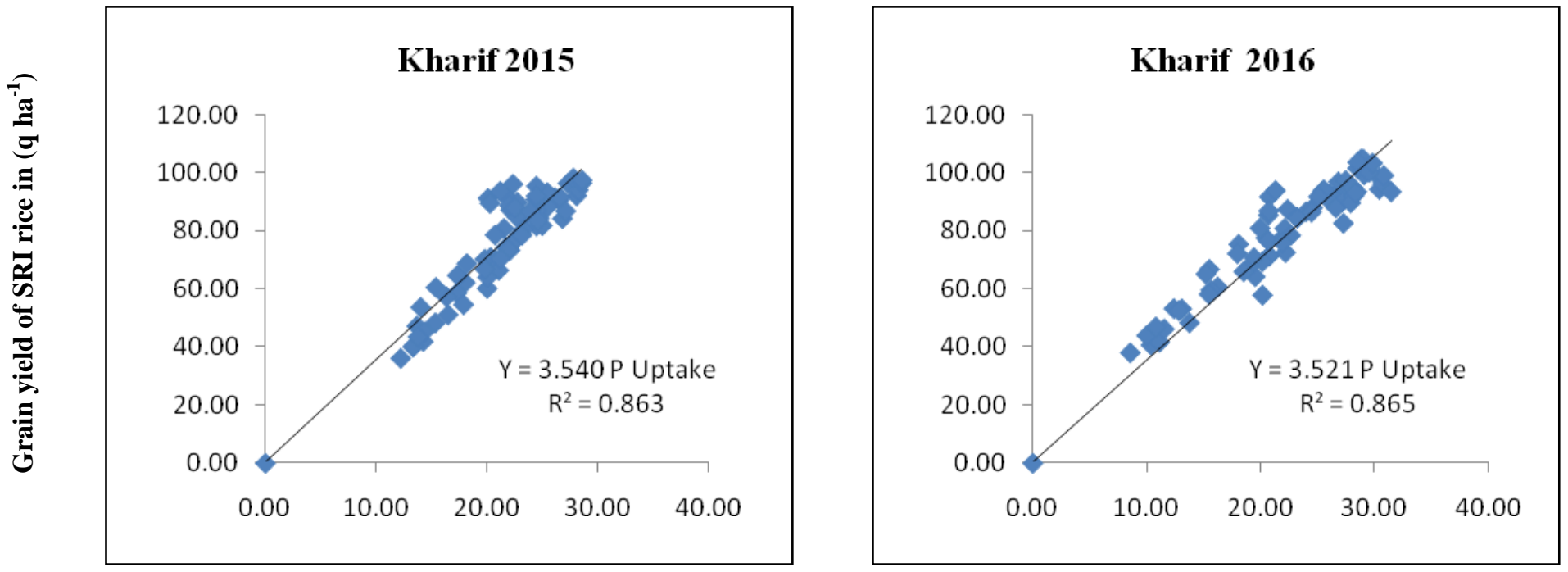

Total P Uptake $\left(\mathrm{kg} \mathrm{ha}^{-1}\right)$

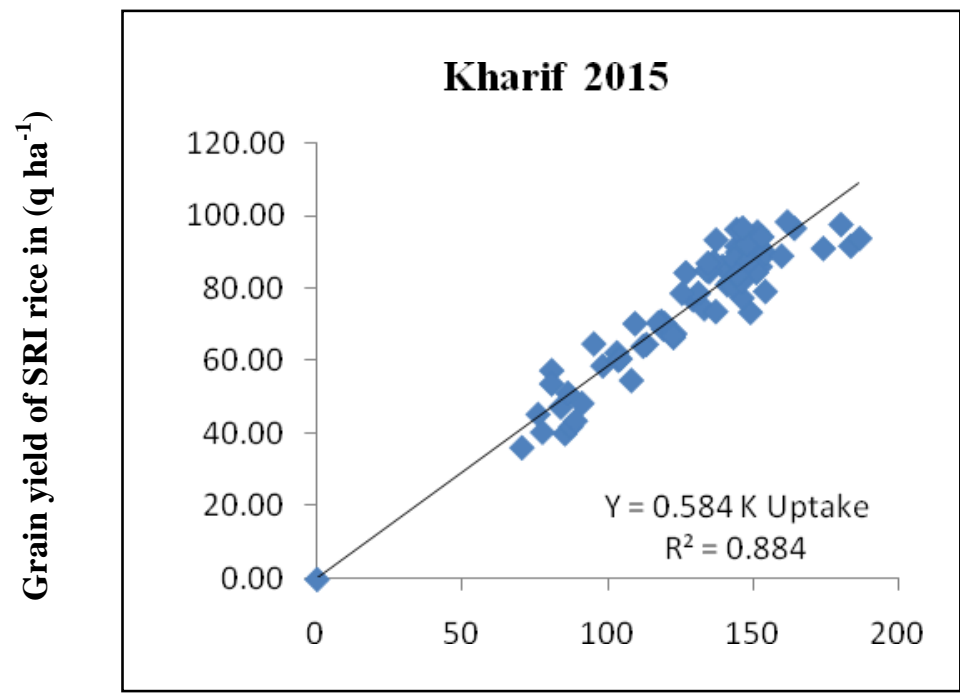

2833

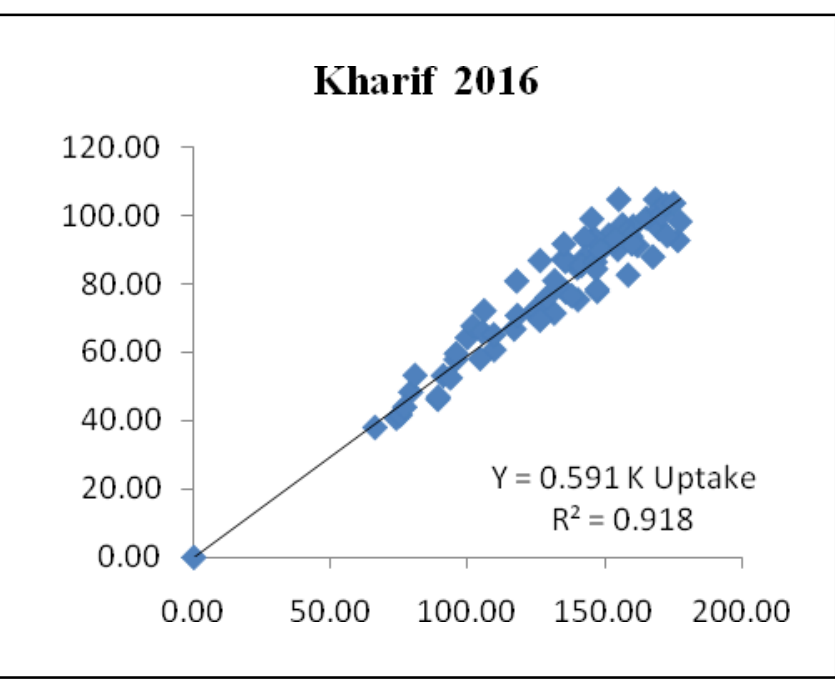

Total K Uptake $\left(\mathrm{kg} \mathrm{ha}^{-1}\right)$ 
The amount of nutrients absorbed by the crop decides a definite amount of biomass production. The amount of nutrient required to produce one quintal of rice grain under SRI method during kharif season 2015 was found to be $1.54 \mathrm{~kg} \mathrm{~N}, 0.29 \mathrm{~kg} \mathrm{P}$ and $1.72 \mathrm{~kg} \mathrm{~K}$ and 1.55 $\mathrm{kg} \mathrm{N}, 0.28 \mathrm{~kg} \mathrm{P}$ and $1.69 \mathrm{~kg} \mathrm{~K}$ in the next kharif season 2016. The overall mean values (Table 6) can be considered as $1.54 \mathrm{~kg} \mathrm{~N}, 0.28 \mathrm{~kg} \mathrm{P}$ and $1.70 \mathrm{~kg} \mathrm{~K}$ to estimate the fertilizer requirement of SRI Rice based on the soil test status to achieve a definite yield target under SRI rice system. Similar kind of trend for mean nutrients requirement was observed at AICRP on STCR, Raipur centre for rice of different duration (Annual progress report 2008, 2009, and 2010).

\section{Efficiencies of fertilizer, soil test and FYM for SRI Rice}

The efficiencies of fertilizer, soil test and FYM were estimated by using the conventional methods with the help of STCR software developed by ICAR-Indian Institute of Soil Science, Bhopal. Table 7 contained the results for rice season, 2015 and 2016. The average values based on two rice season for fertilizer efficiencies of $\mathrm{N}, \mathrm{P}$ and $\mathrm{K}$ were estimated as 40.17, 28.17 and 102.14 per cent, respectively. Similarly, average soil test efficiencies estimated for $\mathrm{N}, \mathrm{P}$ and $\mathrm{K}$ were as $35.02,82.55$ and 17.24 per cent, respectively. The efficiencies of organic source (FYM) were observed as $18.41 \% \mathrm{~N}, 5.58 \% \mathrm{P}$ and $10.79 \%$ $\mathrm{K}$. An identical result for mean contribution from soil and fertilizer nutrients was also reported at AICRP on STCR centre at Raipur for different rice varieties (Annual progress report 2008, 2009, and 2010).

It is well known that $2 / 3^{\text {rd }}$ of the applied fertilizer $\mathrm{N}$ are lost through leaching, volatilization, de-nitrification and by run-off particularly in rice crop. Similarly, a large fraction of applied fertilizer $\mathrm{P}$ is fixed in soil by reacting with dominant cations present in the soil like $\mathrm{Ca}, \mathrm{Mg}, \mathrm{Fe}, \mathrm{Mn}$ etc. High efficiency of applied fertilizer $\mathrm{K}$ observed seems to be due to higher uptake of this nutrient as soil $\mathrm{K}$ status was high in experimental field resulted poor response and due to luxury consumption high $\mathrm{K}$ uptake could be misleading the estimation of applied $\mathrm{K}$ efficiency hence can be treated as indefinable.

\section{Estimation of Fertilizer adjustment equation}

Fertilizer adjustment equations were evolved for SRI rice crop to achieve a definite yield target based on the basic parameters viz. nutrient requirement, efficiencies of fertilizer, soil test and organic source (FYM). The following equations given in Table 4.8 were evolved for SRI rice for fertilizer $\mathrm{N}, \mathrm{P}_{2} \mathrm{O}_{5}$ and $\mathrm{K}_{2} \mathrm{O}$. Many fertilizer adjustment equations have been developed by STCR Raipur centre for different duration of Rice varieties (Annual progress report 2008, 2009, and 2010). Such kind of fertilizer prescription equation for different crops (rice, wheat, maize, mustard and rapeseed) have been documented by MilapChand et al.,(2006), Sharma and Singh (2005), Verma et al.,(2002), Srivastava et al., (2017).

\section{Ready reckoners chart for fertilizer recommendations (SRI Rice)}

The ready reckoners for rice with the use of 5 tones of FYM are shown in Table 9. The fertilizer requirement reduced with the use of FYM resulting in the saving of chemical fertilizer although it is a meager amount however, application of chemical fertilizer with FYM in integrated manner has beneficial by several ways in terms of soil fertility and physical properties improvement. It is further evident that the fertilizer requirements decreased with increase in soil test values. Therefore, a slightly lower yield target may be considered for a poor resource farmers to obtain maximum profit per unit cost spent on fertilizer, whereas, a higher yield target for a resourceful farmers who are interested for maximum potential production per hectare of land. Hence, for maintaining soil fertility, it is necessary to choose appropriate yield targets and fertilizer use practices that achieve the twin objectives of high yield and maintenance of soil fertility. 
However, the maximum target of the crop may be fixed up to the level of maximum yield achieved in experimental field.

Thus the targeted yield approach of fertilizer recommendation ensures nutrient balancing to suit the situations involving different yield goals, soil fertility and resources of the farmer (Dev et al., 1985). Several workers have used this approach of fertilizer prescription (Rashid et al., 1988; Powelson et al., 1989; and Arya, 2003).

\section{References}

Anonymous, 2016, Area, production and productivity of major cereals in India. http//indiastat.com

Arya, V.M., 2003. Fertilizer recommendation based on soil test for rice in Inceptisol and Vertisol of Chhattisgarh. M. Sc. (Agriculture) Thesis, Indira Gandhi Krishi Vishwavidyalaya, Krishak Nagar, Raipur, Chhattisgarh.

Banerjee, H., and Pal, S. 2009. Integrated nutrient management for rice-rice cropping system. Oryza, 46 (1) 32-36.

Dev, G., Dillion, N.S., Brar, J.S. and Vig, A.C. 1985. Soil test based yield targets for wheat and rice-cropping system. Fertilizer News, 30 (5) 42-50.

Mahender Kumar, R., Rama Prasad A.S., Singh, S.P., Ramesha, M.S. and Subbaiah, S.V. 2009. Responses of hybrids to N, P and K in different rice soils. Oryza, 46(4): 293 298.

Pandey, A.K., Kumar Vipin and Kumar Rajesh 2009. Effect of long-term organic and inorganic nutrients on transplanted rice under rice-wheat cropping system. Oryza, Vol. 46. (3), 209-212.

Piper, C.S., 1966. Soil and Plant Analysis. Hans Publisher, Bombay. pp. 85-102.

Powelson, A.K., and Willis, W.D. 1989. Crop response to integrated use of inorganic and organic fertilizer on soil microbial biomass dynamic. Agronomy J., 98: 533539.

Ramamoorthy, B., Narasimhan, R. L. and Dinesh, R.S. 1967. Fertilizer application for specific yield targets of Sonara-64. Indian Farming, 17 (5): 43-45.

Rashid, A., Bugio, N. and Salim, N. 1988. Calibration of three test for determining phosphorus fertility of soil to support cereals, legumes and oilseeds. In: Soil test calibration on West Asia and North Africa, Proceeding of the $2^{\text {nd }}$ Regional Workshop 1-6 Sept. 1987. 86-93.

Santhi, R., Selvakumari, G. and Rani Perumal. 1999. Soil test based fertilizer recommendations under integrated plant nutrition system for rice-rice-pulse cropping sequence. J. Indian Society of Soil Sci., 47: 288-294.

Srivastava, L.K., Mishra, V.N. and Jatav, G.K. 2017. Rice response to fertilizer nutrients as influenced by integrated nutrients management in vertisols of Chhattisgarh plain, India. Int.J.Curr.Microbiol. App.Sci., 6(2): 1709-1719.

Standford, G., Ayres, A.S. and Doi, M. 1965. Mineralizable soil nitrogen in relation to fertilizer needs of sugarcane in Hawai. Soil Sci., 99: 132-137.

\section{How to cite this article:}

Vedhika Sahu, L.K. Srivastava and Mishra, V.N. 2017. Soil Test Based Fertilizer Prescriptions through Integrated Nutrient Management Using Targeted Yield Approach for SRI Rice (Var. Swarna) in Vertisols of Chhattisgarh. Int.J.Curr.Microbiol.App.Sci. 6(9): 2824-2835. doi: https://doi.org/10.20546/ijcmas.2017.609.347 